\title{
Analysis of the Effect of Prognosis Factors for Breast Cancer
}

Mrinal Deka ( $\square$ dekamrinal98@gmail.com )

Assam University

Dibyojyoti Bhattacharjee

Assam University

Research article

Keywords: Prognosis Factor, Logistic Regression, Breast Cancer, Bio Statistics

Posted Date: August 20th, 2020

DOI: https://doi.org/10.21203/rs.3.rs-44838/v1

License: (9) (1) This work is licensed under a Creative Commons Attribution 4.0 International License. Read Full License 


\section{Abstract}

Background: The idea of Prognosis factor is based on the variables that can be used to assess the chance of recovery from a disease. It is also considered as the prior knowledge about any disease before treatment. The concept is applied to the cancer patients to get an idea of how cancer will affect the body and how it will respond to the therapies.

Method: In this paper, selective prognostic factors (Age, Node and Tumour size) are analysed by logistic regression in patients who are suffering from Breast cancer based on data collected from Cachar Cancer Hospital and Research Centre, Silchar, Assam, India.

Results: The study claims that there are 50.1 percent and 65.8 percent chance of remission of cancer for patients of age above 50 in case of breast cancer with below poverty line and above poverty line respectively.

The present study has focused on this cut-off value of $2 \mathrm{~cm}$ as the determining prognostic factor in relation to tumour size. Thus, the chance of remission from cancer is 22.3 percent and 34.7 percent for below poverty line and above poverty line patients respectively, if tumour size is greater than $2 \mathrm{~cm}$.

It also endeavours to ascertain that there are 10.9 percent and 18.1 percent chances of remission of cancer, if the disease has metastasized to regional lymph nodes, with below poverty line and above poverty line respectively.

Conclusion: The parameters viz. Tumour size and Node status, which measure the stage of the cancer patients, are significant prognostic factors that help in predicting tumour behaviour and survival outcomes for breast cancer patients.

\section{Background}

Prognosis factors are defined as the variables that can be used to assess the chance of recovery from a disease. It is also considered as the prior knowledge about any disease before treatment. The concept is applied to the cancer patients to get an idea of how cancer will affect the body and how it will respond to the therapies. It is difficult for the common people to take decision about treatment methods due to lack of knowledge and different socioeconomic backgrounds. Thus, the prior knowledge will benefit the common people to participate in clinical and health policy decisions through prognostic and economic evaluation of cancer treatments. Although many prognostic factors have been identified over the last few decades, affecting the survival outcomes for breast cancer, there are some that have been proven to be of definite significance through various statistical methods. These include - tumour size, nodal status, distant metastasis, histologic grade, histologic type, mitotic figure counts, hormone receptor status like Estrogen Receptor (ER) and Progesterone Receptor (PR) positivity and age of the patient (Russo.et.al, 1987). The present study will focus on tumour size, nodal status and age in relation to survival outcomes far hroact nannor Thnunh thoca fantare aro already proven to be of significant importance in various Loading [MathJax]/jax/output/CommonHTML/jax.js 
studies, the present study will bring out their importance so as to guide future treatment decisions. In addition, the economic status of the patients has been evaluated as a possible demographic factor affecting choice of treatment and the resultant survival outcomes.

It is a matter of serious concern that new cases of the breast cancer are growing up day by day all over the world (Ali.et.al, 2011). Thus, the effect of the prognosis factors on this site of cancer should be studied scientifically so that the patients can get an idea of economic and health policy decisions during the ongoing treatment processes. A comparative study was performed by Kroman.et.al, in the year 2000, among the women who treated through adjuvant cytotoxic treatment and who did not in case of breast cancer. Thus, it is found that there is a negative prognostic effect of young age in women diagnosed with low risk disease who did not receive adjuvant cytotoxic treatment (Kroman.et.al, 2000). Thus, the present paper is mainly focused on the analysis of prognosis factors (Age, Node and Tumour size) for the patients suffering from breast cancer and the findings of present research work will benefit the society for better treatment of cancer.

\section{Objective Of The Study}

The paper is designed keeping in view the following objective:

1. To study the effect of prognosis factors on the breast cancer patients by logistic regression model.

\section{Methods}

The entire data, used in this presence study is a secondary source that is collected from Cachar Cancer Hospital and Research Centre, Silchar, Assam, India. The dataset is stratified on the basis of poverty line (BPL - below poverty line and APL - above poverty line) for normalization. It is necessary to normalize the dataset as the patients included in this study belong to different economic backgrounds. Thus, the patients, who have the BPL card are considered as Below Poverty Line category and those treated without these facilities as Above Poverty Line category.

In this study, data was collected from a total of 400 female patients, half of which belonged to BPL group and the other half to APL group. The following table gives a glimpse of the dataset. 
Table 1

Glimpse of dataset

\begin{tabular}{|c|c|c|c|c|}
\hline Sites of Cancer & Variable & & Frequency & Percentage \\
\hline \multirow{8}{*}{$\begin{array}{l}\text { Breast Cancer } \\
\text { (Below Poverty Line) }\end{array}$} & \multirow[t]{2}{*}{ Gender } & Male & 0 & $0 \%$ \\
\hline & & Female & 200 & $100 \%$ \\
\hline & \multirow[t]{2}{*}{ Age } & Age above 50 & 113 & $56.5 \%$ \\
\hline & & Age below 50 & 87 & $43.5 \%$ \\
\hline & \multirow[t]{2}{*}{ Lymph Node } & Cancer spreads to LN & 70 & $35 \%$ \\
\hline & & Cancer not spreads to LN & 130 & $65 \%$ \\
\hline & \multirow[t]{2}{*}{ Tumour size } & Tumour greater than $2 \mathrm{~cm}$ & 163 & $81.5 \%$ \\
\hline & & Tumour less than $2 \mathrm{~cm}$ & 37 & $18.5 \%$ \\
\hline \multirow{8}{*}{$\begin{array}{l}\text { Breast Cancer } \\
\text { (Above Poverty Line) }\end{array}$} & \multirow[t]{2}{*}{ Gender } & Male & 0 & $0 \%$ \\
\hline & & Female & 200 & $100 \%$ \\
\hline & \multirow[t]{2}{*}{ Age } & Age above 50 & 93 & $46.5 \%$ \\
\hline & & Age below 50 & 107 & $53.5 \%$ \\
\hline & \multirow[t]{2}{*}{ Lymph Node } & Cancer spreads to LN & 65 & $32.5 \%$ \\
\hline & & Cancer not spreads to LN & 135 & $67.5 \%$ \\
\hline & \multirow[t]{2}{*}{ Tumour size } & Tumour greater than $2 \mathrm{~cm}$ & 146 & $73 \%$ \\
\hline & & Tumour less than $2 \mathrm{~cm}$ & 54 & $27 \%$ \\
\hline
\end{tabular}

Binary logistic regression model was applied to observe the probability of remission of disease in the presence of these prognosis factors (Age, Node and Tumour size). It is the chance of an event occurring in a model based on individual characteristics. Because the chance is mainly a ratio, it can be computed as:

$$
p=\frac{e^{\beta_{0}+\beta_{1} x_{1}+\beta_{2} x_{2}+\ldots+\beta_{m} x_{m}}}{1+e^{\beta_{0}+\beta_{1} x_{1}+\beta_{2} x_{2}+\ldots+\beta_{m} x_{m}}}
$$

where $p$ indicates the probability of an event, $\beta_{i}$ 's are the regression coefficients associated with the reference group and $x_{i}^{\prime}$ s are the explanatory variables(Francis R., 2017). 
In this present study, it will be convenient if we write our binary logistic regression model as follows:

$$
p=\frac{e^{\beta_{0}+\beta_{1} x_{1}+\beta_{2} x_{2}+\beta_{3} x_{3}}}{1+e^{\beta_{0}+\beta_{1} x_{1}+\beta_{2} x_{2}+\beta_{3} x_{3}}}
$$

where $p=$ Probability of remission of cancer

$x_{i}=$ Age of the patients

$x_{2}=$ Node status of the cancer

$x_{3}=$ Tumour size of the cancer

Thus, we can write the model as follows.

$$
\operatorname{logit}(p)=\beta_{0}+\beta_{1} \times \text { Age }+\beta_{2} \times \text { Nodestatus }+\beta_{3} \times \text { Tumoursize }
$$

\section{Results}

The purpose of applying logistic regression model is to observe the probability of remission from the cancer in the presence of the three prognosis factors viz. Age, Node and Tumour size. The analyses are done separately for both categories (BPL and APL) of breast cancer. 
Table 2

Analysis of logistic regression model for breast cancer with below poverty line (BPL) category

\begin{tabular}{|c|c|c|c|c|c|c|c|c|}
\hline \multirow[t]{2}{*}{ Prognosis Factors } & \multirow[t]{2}{*}{ B } & \multirow[t]{2}{*}{ S.E } & \multirow[t]{2}{*}{ Wald } & \multirow[t]{2}{*}{ df } & \multirow[t]{2}{*}{ Sig. } & \multirow{2}{*}{$\begin{array}{l}\text { Odds } \\
\text { ratio }\end{array}$} & \multicolumn{2}{|l|}{$95 \% \mathrm{Cl}$} \\
\hline & & & & & & & Lower & Upper \\
\hline Age above 50 & 0.663 & 0.291 & 5.203 & 1 & 0.023 & 1.501 & 1.098 & 3.432 \\
\hline \multicolumn{9}{|l|}{ Yes } \\
\hline \multicolumn{9}{|l|}{$\mathrm{No} \circledast$} \\
\hline $\begin{array}{l}\text { Cancer spread to Lymph } \\
\text { Node }\end{array}$ & 0.737 & 0.333 & 4.897 & 1 & 0.027 & 1.109 & 1.088 & 4.016 \\
\hline \multicolumn{9}{|l|}{ Yes } \\
\hline \multicolumn{9}{|l|}{$\mathrm{No} \circledast$} \\
\hline $\begin{array}{l}\text { Tumour size is greater than } \\
2 \mathrm{~cm}\end{array}$ & 0.889 & 0.331 & 7.208 & 1 & 0.007 & 1.223 & 1.271 & 4.654 \\
\hline \multicolumn{9}{|l|}{ Yes } \\
\hline \multicolumn{9}{|l|}{$\mathrm{No}{ }^{\circledR}$} \\
\hline Constant & 0.392 & 0.259 & 2.293 & 1 & .0130 & 1.480 & - & - \\
\hline
\end{tabular}

We have obtained from Table 2 that in case of breast cancer with below poverty line category, there is 50.1 percent chance of remission from the cancer if the patient age is above 50 , which is better in comparison to that for patient age below 50 . Again, if the cancer has already metastasized to axillary lymph nodes, the chance of remission from the cancer is only 10.9 percent, which is worse as compared to the cancer that has not spread to the lymph nodes. The patients with tumour size greater than $2 \mathrm{~cm}$ have 22.3 percent chance of remission from cancer after the treatment, which is worse in comparison to the patients with the size of tumour less than $2 \mathrm{~cm}$. 
Table 3

Analysis of logistic regression model for breast cancer with above poverty line (APL) category

\begin{tabular}{|c|c|c|c|c|c|c|c|c|}
\hline \multirow[t]{2}{*}{ Variables } & \multirow[t]{2}{*}{ B } & \multirow[t]{2}{*}{ S.E } & \multirow[t]{2}{*}{ Wald } & \multirow[t]{2}{*}{ df } & \multirow[t]{2}{*}{ Sig. } & \multirow{2}{*}{$\begin{array}{l}\text { Odds } \\
\text { ratio }\end{array}$} & \multicolumn{2}{|l|}{$95 \% \mathrm{Cl}$} \\
\hline & & & & & & & Lower & Upper \\
\hline Age above 50 & 1.043 & 0.366 & 8.111 & 1 & 0.004 & 1.658 & 1.384 & 5.817 \\
\hline \multicolumn{9}{|l|}{ Yes } \\
\hline \multicolumn{9}{|l|}{$\mathrm{No} \circledast$} \\
\hline $\begin{array}{l}\text { Cancer spread to Lymph } \\
\text { Node }\end{array}$ & 1.051 & 0.516 & 4.152 & 1 & 0.042 & 1.181 & 1.041 & 5.864 \\
\hline \multicolumn{9}{|l|}{ Yes } \\
\hline \multicolumn{9}{|l|}{$\mathrm{No} \circledast$} \\
\hline $\begin{array}{l}\text { Tumour size is greater than } \\
2 \mathrm{~cm}\end{array}$ & 1.299 & 0.555 & 5.484 & 1 & 0.019 & 1.347 & 1.236 & 3.877 \\
\hline \multicolumn{9}{|l|}{ Yes } \\
\hline \multicolumn{9}{|l|}{$\mathrm{No} \circledast$} \\
\hline Constant & -2.398 & 0.522 & 6.083 & 1 & 0.000 & 0.091 & - & - \\
\hline
\end{tabular}

Similarly, from Table 3, it is obtained that there is 65.8 percent more chance of remission from the cancer if the patient age is above 50 in the comparison to the patient of age below 50 . Again, if the cancer has already metastasized to axillary lymph nodes, the chance of remission from the cancer is only 18.1 percent as compared to the cancer that has not metastasized to regional lymph nodes. The patients with tumour size greater than $2 \mathrm{~cm}$ have 34.7 percent chance of remission of cancer in the comparison to the patients with the size of tumour less than $2 \mathrm{~cm}$ in case of breast cancer with above poverty line category.

\section{Discussion}

Preclusion of cancer is one of the most significant public health challenges of the 21 st century (Ali.et.al, 2011). Further, new cases of breast cancer show an ever increasing incidence all over the world. Several prognostic factors have been identified which affect the outcomes of disease and treatment. Thus, the present study is mainly focused on the chance of remission of cancer in relation to three prognostic factors viz. Age, Node and Tumour size for the patients that are suffering from breast cancer.

The age of the patient is a well-defined prognosis factor for local recurrence. It is well established that patient age greater than 35 or 40 is associated with an increased frequency of local recurrence due to presence of various adverse pathologic features, such as lymph vascular invasion, grade 3 histology, Loading [MathJax]/jax/output/CommonHTML/jax.js 
extensive intra-ductal component (Kollias. et.al, 1997). Our study finds that there are 50.1 percent and 65.8 percent chance of remission of cancer for patients of age above 50 in case of breast cancer with below poverty line and above poverty line respectively. Thus, in agreement with previous studies, we can consider the higher age as good prognostic factor and younger age as poor prognostic factor in breast cancer.

Tumour size is considered to be the best measure of tumour behaviour in breast cancer. Patients with a primary tumour size of less than $1 \mathrm{~cm}$ exhibit a frequency of only 10 percent to 20 percent for nodal metastasis, such that the 10-year disease-free survival rate is about 90 percent (Carter.et.al, 1989). Since the American Joint Committee on Cancer (AJCC) has described tumour size less than or equal to $2 \mathrm{~cm}$ as $T 1$, the present study has focused on this cut-off value of $2 \mathrm{~cm}$ as the determining prognostic factor in relation to tumour size. The chance of remission from cancer is 22.3 percent and 34.7 percent for BPL and APL patients respectively, if tumour size is greater than $2 \mathrm{~cm}$.

Axillary lymph node status has been described as the second most important prognostic factor in relation to disease-free survival, as well as overall survival in breast cancer. 70 percent of node positive patients are likely to develop recurrence compared to only 20 percent to 30 percent of node-negative patients (Veronesi.et.al, 1993). Patients with 4 or more number of involved nodes have worse prognosis when compared to those with less than 4 nodes (Fisher.et.al, 1993). It is found from our study that there are 10.9 percent and 18.1 percent chances of remission of cancer, if the disease has metastasized to regional lymph nodes, with below poverty line and above poverty line respectively. Thus it can be concluded that the parameters viz. Tumour size and Node status, which measure the stage of the cancer patients are significant prognostic factors that help in predicting tumour behaviour and survival outcomes.

\section{Conclusion}

The present study has successfully brought out the relationship between specific prognostic factors and survival outcomes in breast cancer. The application of logistic regression model to the selected prognostic factors has revealed that a tumour size greater than $2 \mathrm{~cm}$ denotes a dismal prognosis, as does presence of axillary nodal involvement. Also, patient's age less than 50 years is associated with worse prognosis and poor overall survival.

\section{List Of Abbreviations}




\begin{tabular}{|ll|}
\hline Abbreviations & Meaning \\
\hline cm & Centimetre \\
\hline ER & Estrogen Receptor \\
\hline APL & Progesterone Receptor \\
\hline BPL & Above Poverty Line \\
\hline LN & Below Poverty Line \\
\hline p & Lymph Nodes \\
\hline & Probability of remission of cancer \\
\hline logit( $p)$ & Regression Coefficients \\
\hline B & Explanatory Variables \\
\hline S.E & Logarithm of the odds, where p is the probability \\
\hline Wald & Standard Error \\
\hline d.f. & Wald Statistic \\
\hline Sig. & Degrees of freedom \\
\hline Cl & Significant \\
\hline B & Confidence Interval \\
\hline HER2 & Reference Category \\
\hline AJCC & Namely \\
\hline T1 & Tumour Epidermal Growth Factor Receptor 2 \\
\hline
\end{tabular}

\section{Declarations}

\section{Ethics approval and consent to participate}

The project was presented in front of Institutional Ethics Committee (IEC), Assam university, Silchar, Assam, India on $3^{\text {rd }}$ April, 2019 (03/04/2019). The venue of the meeting was in the UGC-SAP conference Hall, Department of Life Science and Bioinformatics, Assam university, Silchar, Assam, India. 
The Institutional Ethics Committee (IEC) had took the decision that the project falls under exempted category as no participation of Human volunteer is directly involved and data will be collected from secondary sources.

The administration of the hospital (Cachar Cancer Hospital and Research Centre) had granted the permission to access and use the medical records for this particular study. The ethical committee decision report and permission letter of the hospital have been attached in the supplementary materials section through online process.

\section{Consent for publication}

"Not applicable"

\section{Availability of data and material}

All data generated or analysed during this study are included in this published article [and its supplementary information files].

\section{Competing interests}

The authors declare that they have no competing interests.

\section{Funding}

"Not applicable"

\section{Authors' contributions}

The corresponding author of this paper is MD, who has analysed the data and interpret the result as well as writing the whole manuscript.

DJB is the co-author of this manuscript and contribute himself as the supervisor as well as guardian of this project.

It has been declared that all authors have read and approved the manuscript.

\section{Acknowledgements}

The authors would like to take this opportunity of expressing their gratitude and acknowledging their indebtedness to the director of Cachar Cancer Hospital and Research Centre, Dr Ravi Kannan sir and the hospital staffs for the permission and providing the required dataset for this project.

\section{References}


2. Carter $\mathrm{CL}$, Allen $\mathrm{C}$, Henson DE. Relation of tumour size, lymph node status and survival in 24740 breast cancer cases. Cancer. 1989;63:181-7.

3. Fisher ER, Anderson S, Redmond C, Fisher B. Pathologic findings from the national surgical adjuvant breast project protocol B-06: 10-year pathologic and clinical prognostic discriminants. Cancer. 1993;71:2507-14.

4. Francis R. The application of binary logistic regression analysis on staff performance appraisal. Science J Applied Mathematics Statistics. 2017;4:164-8.

5. Kleinbaum D, Klein M. Survival Analysis, A self-learning text. 3rd edi. Springer. 2012.

6. Kollias J, Elston CE, Ellis IO, Robertson JFR, Blamey RW. Early-onset breast cancer: histopathological and prognostic considerations. British J Cancer. 1997;75:1318-23.

7. Kroman N, Jensen M. Factors influencing the effect of age on prognosis in breast cancer: population based study. 2000. British Med J.

8. Rosen PP, Groshen S, Kinne DW, Norton L. Factors influencing prognosis in node-negative breast carcinoma: analysis of 767 T1NOMO/T2NOM0 patients with long-term follow up. J Clinical Oncol. 1993;11:2090-100.

9. Russo J, Frederick J. Predictors of recurrence and survival of patients with breast cancer. Am J Clinical Patho. 1987;88:123-31.

10. Seidman JD, Schnaper LA, Aisner SC. Relationship of the size of the invasive component of the primary breast carcinoma to axillary lymph node metastasis. Cancer. 1995;75:65-71.

11. Smith JA, Gallager HS. Carcinoma of the breast: analysis of total lymph node involvement versus level of metastasis. Cancer. 1997;39:527-32.

12. Veronesi U, Galimberti V, Zurrida S. Prognostic significance of number and level of axillary node metastases in breast cancer. The Breast. 1993;2:224-8.

\section{Supplementary Files}

This is a list of supplementary files associated with this preprint. Click to download.

- RevisedDataset.xlsx 